\title{
Original
}

\section{Determination of Total and Ionic Fluoride in Formula Milk Produced in Japan}

\author{
乳児用調整粉乳中の総フッ素およびイオン型フッ素の測定
}

\author{
Misako TOMITA*, Takako SUGIMURA*, \\ Masahide KOYAMA* and Yoshihiro KANEKO*
}

富田美佐子* 杉村たか子*

古山公 英 ${ }^{*}$ 金子芳 洋 ${ }^{*}$

Received January 30, 1992 ; Accepted March 10, 1992

概要：母乳および乳児用調整粉乳中のフッ素の測定は，測定法の進歩にもかかわらず，多有機啠中の微量 フッ素测定の困難さから，イオン型フッ素と総フッ素の割合およびその存在様態なとも明らかではない。 本研究ではわが国における市販乳児用調整粉乳20種について，4種の測定法を行ない，それぞれの值を比 較検討した。

試料は市販乳児用調整粉乳（ 5 社，20種類，そのうち 6 種は大豆ベース 2 種を含む特殊調整粉乳）を製造 会社の指定する標準源度に蒸留水で希釈した $(0.13 \sim 0.17 \mathrm{~g} / \mathrm{m} l)$ 。また微量拉散の操作条件を検郡するため市 販牛乳 2 種を用いた。

フッ素の測定はフッ素イオン電極による直接測定（IE 法）以外はガスクロマトグラフィーにより行なっ た。前処理法として(1)微量拡散法 (Dif 法) (2)パイロハイドロリシス法 (PyH 法) (3)低温灰化法 (LTA 法) を用いたが，それらの装置と条件，フッ素の添加回収率等にっいてはすでに報告している。Dif 法にっいて は, 拡散時間（1２4時間）と過塩素酸の莀度（ $2.7 \mathrm{M}$ と9.2 M) をかえ, 乳児用調整粉乳と牛乳にっいて 検討した。

その結果，イオン型フッ素を測定する IE 法と Dif 法によるフッ素測定值は殆どの場合一致せず, Dif 法 からの值の方が高かった。我々がすでに検討した牛乳中のイオン型フッ素は浱い酸を用い，12時間以上拉散 を行なっても IE 法の值を上回ることはなかったが，それと反対の現象をみとめた。Dif 法の再検討を行な った成績も同様に Dif 法の值が IE 法の值より高く,これらの結果は乳児用調整粉乳中のイオン型フッ素 には,フリー (free) と酸不安定 (acid labile) の 2 つの型が存在することを示唆している。

総フッ素については，LTA 法で測定した值が $\mathrm{PyH}$ 法で測定した值よりわずかに高い傾向がみられた (Wilcoxon's signed ranks test)。しかし, PyH 法の值と Dif 法の值は数種の例外を除いて近似していた。 このことから，乳児用調整粉乳中のフッ素測定において，Dif 法を简易法として用いることができるである う。

今回測定した乳児用調整粉乳のフリーのイオン型フッ素は0.010 0.178 $\mu \mathrm{g} / \mathrm{m} l$; 総フッ素は $0.033 \sim 0.210$ $\mu \mathrm{g} / \mathrm{m} l(\mathrm{PyH}$ 法 $)$ を示し，それらの平均値は $0.048 と 0.070 \mu \mathrm{g} / \mathrm{m} l$ となった。また，大豆べースを含む特殊調

* Department of Hygiene and Oral Health, School of Dentistry, Showa University (Chief: Prof. Yoshihiro KANEKO)

* 昭和大学歯学部口腔衛生学教室（主任：金子芳洋教授） 
整粉乳中のフッ素の平均值については武料数が少ないので別個に求めてはいないが，必ずしも高いとはいえ ない。

\title{
Koy words : Ionic fluoride, Total fluoride, Infant formula milk, Measurement
}

\author{
索引用語 : イオン型フッ素，総フッ素，乳児用調整粉乳，測定法
}

\section{Introduction}

Determining the fluoride $(F)$ level in infant formula milk and human milk is important to estimate the amount of $F$ intake in early infancy. In recent years, reports ${ }^{1-8)}$ of an increased prevalence of dental fluorosis in both fluoridated and nonfluoridated areas have led to a reassessment of the amount of $F$ being ingested by infants. To achieve such a reassessment, it is essential to have accurate determination methods for ionic and total (ionic plus bound) $\mathrm{F}$ in infant foods.

Although in the early $1970 \mathrm{~s}$ the determination of $\mathrm{F}$ in milk was done for both ionic and total $\mathrm{F}^{4-7)}$, Singer et al $^{\mathrm{g})}$ and Taves ${ }^{9)}$ reported that there was no discrepancy between the values of total $\mathrm{F}$ obtained by the ashing method and those of ionic $F$ obtained by the unashing method in most of the food groups studied. A recent collaborative study by Dabeka et al. ${ }^{10)}$ has recommended a method based on acid diffusion from unashed samples for determining $F$ in infant foods. Given these circumstances, current studies ${ }^{11-17)}$ which have evaluated the $F$ content of infant foods have measured only ionic $F$ by various diffusion methods.

However, according to a report by van Staden $e t$ al. ${ }^{18)}$, they measured ionic and ionizable $F$ in milk using various reported diffusion methods and found that the recovery of ionic $\mathrm{F}$ was insufficient in almost all the methods examined. Rao' ${ }^{19}$ stated in his review that no convenient and broadly accepted method had yet been found to determine the amount of $\mathrm{F}$ in foods and beverages. The determination of total $\mathrm{F}$ in milk is difficult because milk contains high amounts of organic matter while its $F$ content is low. Therefore, different analytical procedures have produced a wide range of reported $F$ levels in milk, and the ratio of ionic and total $F$ levels in milk is not yet clear.

In this context, we previously reported total and ionic $\mathrm{F}$ levels in cow' milk measured by three analytical procedures ${ }^{20)}$. This time, we determined and compared the results of total and ionic $\mathrm{F}$ content in formula milk samples obtained in Japan using four analytical procedures.

\section{Materials and methods}

Formula milk: Twenty kinds of powdered formula milk (5 manufacturers), regular type milk-based and specialized formula including soy-based products, were purchased locally and used for analysis. We determined the $\mathrm{F}$ content in formula milk diluted with distilled water according to the manufacturer's directions. The concentrations of milk powder were from 13 to $17 \mathrm{~g}$ per $100 \mathrm{~m} l$ of distilled water.

Cows' milk: Two kinds of cows' milk were purchased and used for examining the microdiffusion operating conditions compared with those of formula milk.

$\mathrm{F}$ analysis : Ionic $\mathrm{F}$ was determined by the $\mathrm{F}$ ion selective electrode (IE) method and the microdiffusion (Dif) method, while pyrohydrolysis $(\mathrm{PyH})$ and low temperature plasma ashing (LTA) were used for pretreatment of the total $\mathrm{F}$ determination. The $\mathrm{F}$ separated from the milk component was measured by gas chromatography (GC). Although we have already reported the procedures for the above-mentioned methods ${ }^{20-24)}$, in this study we used strontium as a fixative for the LTA method.

Reexamination of the Dif method: The effects of diffusion time (1-24 hrs) and acid concentrations (2.7 $\mathrm{M}$ and 9.2 $\mathrm{M}$ perchloric acid) on the $\mathrm{F}$ values in formula milk and cows' milk were examined again. 
Table 1 Total and ionic F levels in formula milk diluted with distilled water

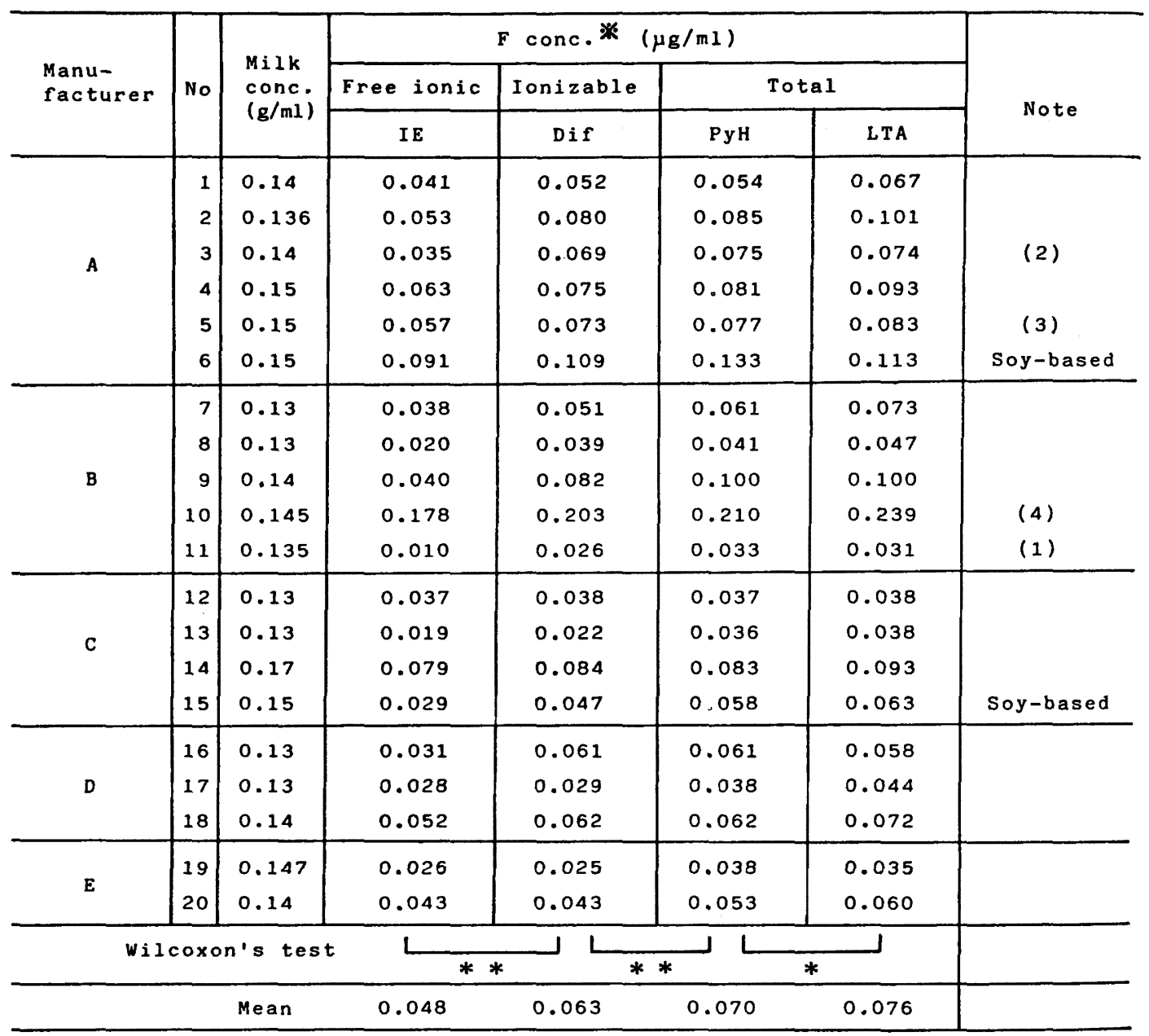

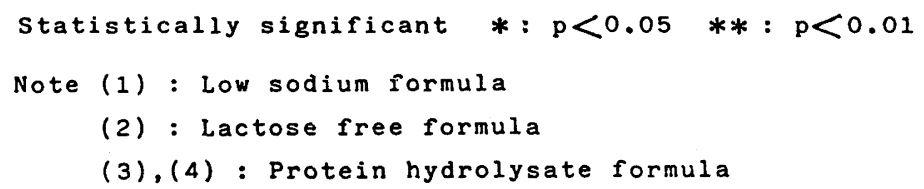

\section{Results}

$\mathrm{F}$ levels in formula milk: The $\mathrm{F}$ levels in formula milk determined by four methods are shown in Table 1 and the relationships of each value are shown in Fig. 1. The ionic $F$ values determined by the $\mathrm{IE}$ and the Dif methods did not agree with each other in almost all the samples: the values from the Dif method were higher than the values from the IE method. These findings revealed a large difference from the results in our previous experiments on cows' milk ${ }^{20)}$. The total $\mathrm{F}$ values obtained by the LTA method were generally slightly higer than those of the PyH method. 


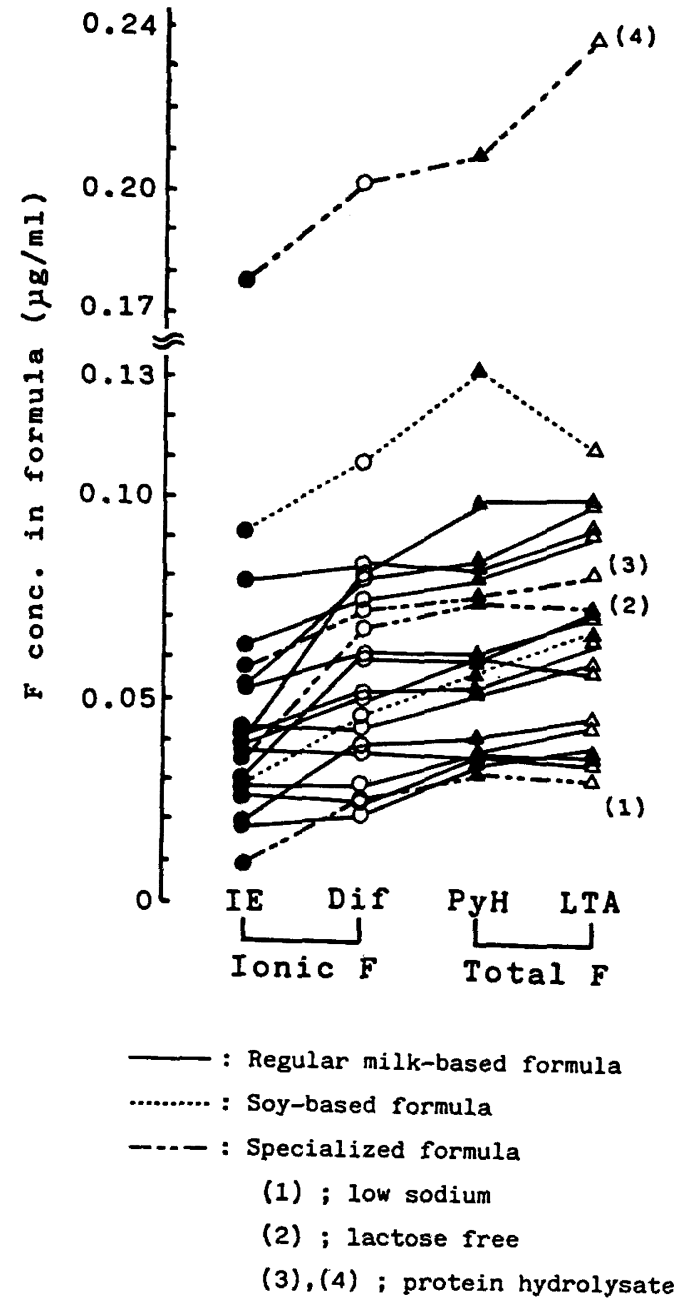

Fig. 1 Relationships of $F$ values in formula milk obtained by the four methods
Using Wilcoxon's signed ranks test, statistically significant differences were observed between the $F$ values obtained with the IE method and those of the Dif method $(p<0.01)$, and differences were also observed between the $F$ values from the $\mathrm{PyH}$ method and those from the LTA method $(p<0.05)$.

The ionizable $F$ values from the Dit method showed only a little difference from the total $\mathrm{F}$ values given by the $\mathrm{PyH}$ method although there were. some exceptions, and the $\mathrm{PyH}$ method always gave slightly higher values than the Dif method.

The $F$ values of arithmetic mean in the formula milk diluted with distilled water obtained by the four methods were 0.048 for the IE, 0.063 for the Dif, 0.070 for the $\mathrm{PyH}$, and 0.076 $\mu \mathrm{g} / \mathrm{m} l$ for the LTA.

The ratios of $F$ values given by the Dif, $\mathrm{PyH}$, and LTA methods to the free ionic $\mathrm{F}$ given by the IE method are shown in Table 2 . The ratios of total $F$ to free ionic $F$ had a wide range, from 1.0 to 3.3 (in the $\mathrm{PyH}$ method). The ratios of acid labile $F$ (substracting the $F$ value obtained by the IE method from the $F$ value obtained by the Dif method) to free ionic $F$ showed a range from -0.04 to 1.6 .

Reexamination of the Dif method: The effects of diffusion time and perchloric acid concentrations on the $F$ values determined in the formula milk and the cows' milk are indicated in Fig. 2. The results of the cows' milk were the same as previous experimental data ${ }^{20)}$; the $\mathrm{F}$ values given by the Dif method did not exceed the values which were measured by the IE method even after a diffusion time of 24 hours. However, in the case of formula milk, the $F$ values given by the Dif method were higher than those of the IE method even after 1 hour of diffusion with $2.7 \mathrm{M}$ perchloric acid.

\section{Discussion}

Ionic $F$-in formula milk: It is now generally agreed that although the $F$ content in drinking water is in ionic or free form, foods and beverages contain both ionic and nonionic, or bound forms of $F$. Moreover, the analysis of ionic $\mathrm{F}$ in drinking water is relatively straightforward; on the other hand, no convenient and adequate method is generally accepted for the analysis of total $F$ in foods and beverages at this time ${ }^{19)}$.

Even though the use of the diffusion technique for the determination of ionic $F$ in milk is generally 
Table 2 Ratios of $F$ values to free ionic $F$ obtained by the IE method

\begin{tabular}{c|ccccc}
\hline \multirow{2}{*}{ Milk No } & \multicolumn{3}{|c}{ Ratios of F values to free ionic F } \\
\cline { 2 - 4 } & Acid labile & Ionizable & \multicolumn{2}{c}{ Total } \\
\cline { 2 - 4 } & (Dif-IE)/IE & Dif/IE & PyH/IE & LTA/IE \\
\hline 1 & 0.27 & 1.27 & 1.32 & 1.63 \\
2 & 0.51 & 1.51 & 1.60 & 1.91 \\
4 & 0.97 & 1.97 & 2.14 & 2.11 \\
5 & 0.19 & 1.19 & 1.29 & 1.48 \\
6 & 0.28 & 1.28 & 1.35 & 1.46 \\
7 & 0.20 & 1.20 & 1.46 & 1.24 \\
8 & 0.34 & 1.34 & 1.61 & 1.92 \\
9 & 0.95 & 1.95 & 2.05 & 2.35 \\
10 & 1.05 & 2.05 & 2.50 & 2.50 \\
11 & 0.14 & 1.14 & 1.18 & 1.34 \\
12 & 1.60 & 2.60 & 3.30 & 3.10 \\
13 & 0.03 & 1.03 & 1.00 & 1.03 \\
14 & 0.16 & 1.16 & 1.89 & 2.00 \\
15 & 0.63 & 1.06 & 1.05 & 1.18 \\
16 & 0.62 & 1.62 & 2.00 & 2.17 \\
17 & 0.97 & 1.97 & 1.97 & 1.87 \\
18 & 0.04 & 1.04 & 1.36 & 1.57 \\
19 & 0.19 & 1.19 & 1.19 & 1.38 \\
20 & -0.04 & 0.96 & 1.46 & 1.35 \\
\hline Mean & 0.00 & 1.00 & 1.23 & 1.40 \\
\pm SD & 0.43 & 1.43 & 1.65 & 1.75 \\
\hline & 0.45 & 0.45 & 0.56 & 0.52 \\
\hline
\end{tabular}

considered very accurate, the values reported from different laboratories continue to span a wide range and many different opinions still exist ${ }^{18}$. According to some reports, ${ }^{4}$ ) some part of the $F$ which is added to the milk remains in a free ionic state while the remainder becomes bound to the milk constituents.

We have reported ${ }^{20)}$ that the direct measurement of ionic $\mathrm{F}$ in cows' milk by an ion-selective electrode made it possible to measure the $\mathrm{F}$ concentration down to a third decimal place with good reproducibility by correcting the calibration curve with a suitable standard solution between each measurement. This time, measurements of ionic $\mathrm{F}$ in formula milk by the IE method were performed in the same manner as in cows' milk and good reproducibility was also observed.

In reexamination of the Dif method, which showed higher $F$ values from the Dif method than those from the IE method only for the formula milk, we discovered that there were two forms of ionic $F$ in formula milk, one free and the other acid labile. In blood serum, however, Paez et al. ${ }^{25)}$ reported that a labile fraction can be detected in a combined or organic fraction depending on the intensity of the treatment applied in order to obtain the separation of total F. In the formula milk we found the acid labile form, which could not be found in blood serum and cows' milk in our previous studies ${ }^{20,22)}$.

Total $\mathrm{F}$ in formula milk: The values for total $\mathrm{F}$ in the LTA method generally were slightly higher than in the $\mathrm{PyH}$ method. We believe these differences were related to the specific character of the 
를

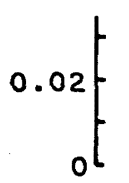

(4)
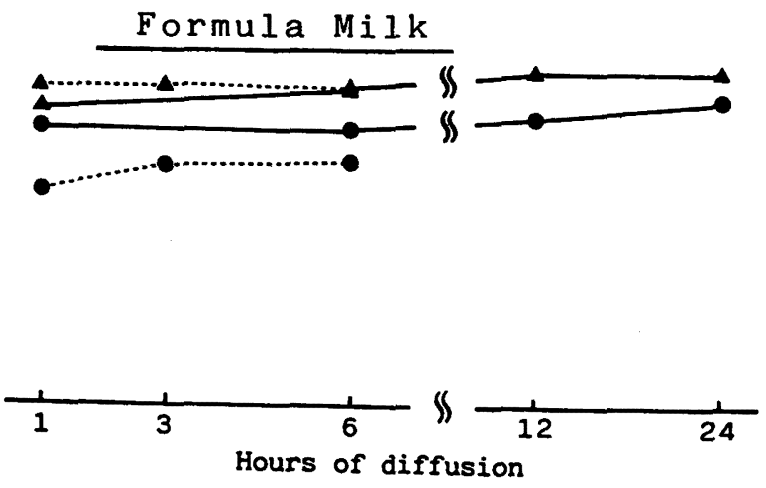

(o) $(\Delta)$

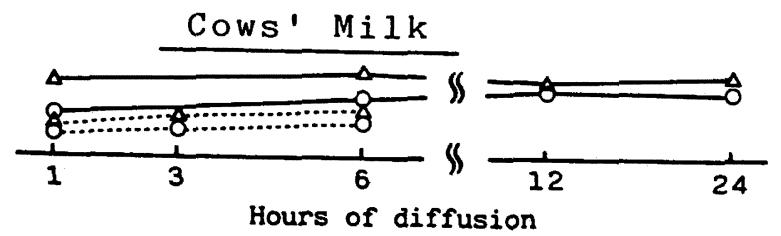

- : Formula milk (No.3)

....... : $2.7 \mathrm{M} \mathrm{HClO}_{4}$

- : Formula milk (No.9)

$: 9.2 \mathrm{M} \mathrm{HClO}_{4}$

0 : Cows' milk A

$\Delta$ : Cows' milk B

$(\bullet),(\Delta),(0),(\Delta): F$ values given by the IE method (free ionic $F$ )

Fig. 2 Effect of diffusion time and acid concentrations on $\mathrm{F}$ values

F pretreatment methods; that is, with the $\mathrm{PyH}$ method, the $\mathrm{F}$ isolated from samples was determined; however, with the LTA method, the $F$ which remained in the ashed samples was determined. As we have experienced in the ashing of cows' milk ${ }^{20)}$, the $F$ values from the LTA method were affected by ashing time; ashing time beyond 8 hours resulted in a gradual increase in $F$ values.

Although a significant difference was recognized statistically in the $F$ values between the Dif method and the $\mathrm{PyH}$ method, both values showed considerable agreement in each sample. Our results are in close agreement with Taves's report ${ }^{9)}$ that no discrepancy between the $F$ values from ashed (total $F$ ) and unashed (inorganic F) samples was found in most of the food groups treated. Therefore, when highly precise data and special equipment are not required for the experiments, we recommend that the Dif method on unashed samples be used in place of the determination of total $F$ on ashed samples in formula milk.

Comparison with other published data: Recently, Watanabe et al. ${ }^{26)}$ reported that the total $\mathrm{F}$ values in formula milk purchased locally in Japan and diluted with distilled water were from 0.03 to $0.07 \mu \mathrm{g} /$ $\mathrm{ml}$. McKnight-Hanes et al. ${ }^{15)}$ reported that soy-based formulas contained higher levels of $\mathrm{F}$ than their milk-based counterparts. We purchased and used twenty kinds of powdered formula milk, regular type milk-based formula, and specialized formula including soy-based products. The specialized formula milk is produced for infants who require special treatment for metabolic disorders; these formulas are low sodium, lactose free and protein hydrolysate. Because the number of samples used in our experiment was limited, we did not separately calculate the average $\mathrm{F}$ concentrations in the specialized formulas or in the regular formulas. However, the $F$ concentrations in the specialized formulas had levels similar to those of the regular formulas, although there were a few exceptions. 
Our results for total $\mathrm{F}$ ranged from 0.033 to $0.210 \mu \mathrm{g} / \mathrm{ml}$ (obtained by the $\mathrm{PyH}$ method), equivalent to 0.004 to $0.031 \mathrm{mg} \mathrm{F} / 100 \mathrm{kcal}$; the average was $0.070 \mu \mathrm{g} \mathrm{F} / \mathrm{ml}$, equivalent to $0.01 \mathrm{mg} \mathrm{F} / 100 \mathrm{kcal}$. These figures do not exceed the upper limit of $0.06 \mathrm{mg} \mathrm{F} / 100 \mathrm{kcal}$ for powdered formulas recommended by Ekstrand $^{27)}$.

Ekstrand stated in his paper ${ }^{27)}$ that the $F$ concentrations ranged from 0.1 to $0.8 \mathrm{mg} / l$ for ready-tofeed milk-based formulas and this variation depended mainly on the $F$ concentration of water used in preparing the products. In Japan, because the amount of $F$ in most water supplies is low $(0.1-0.2 \mathrm{mg} / l)$, the $\mathrm{F}$ concentrations in formula milk diluted with tap water would not reach the intake of $0.1 \mathrm{mg} \mathrm{F} / \mathrm{kg}$ body weight/day commonly believed to be associated with increased risk of developing dental fluorosis ${ }^{28}$.

\section{References}

1) Aasenden, R. and Peebles, T. C.: Effects of fluoride supplementation from birth on deciduous and permanent teeth, Arch. Oral Biol., 19 ; 321-326, 1978.

2) Forsman, B. : Early supply of fluoride and enamel fluorosis, Scand. J. Dent. Res., 85 ; 22-30, 1977.

3) Leverett, D.: Prevalence of dental fluorosis in fluoridated and nonfluoridated communities-a preliminary investigation, J. Public Health Dent., 46 ; 184-187, 1986.

4) Dalziel, J. A. W. and Dangi, A. V.: The determination of free and total fluoride in milk, Proc. Soc. Anal. Chem., 9 ; 197, 1972.

5) Dirks, O. B., Jongeling-Eijndhoven, J. M. P. A., Flissebaalje, T. D. and Gedalia, I. : Total and free ionic fluoride in human and cow's milk as determined by gas-liquid chromatography and the fluoride electrode, Caries Res., 8 ; 181-186, 1974.

6) Addir, S. M. and Wei, S. H. Y.: Supplemental fluoride recommendations for infants based on dietary fluoride intake, Caries Res., $12 ; 76-82,1978$.

7) Duff, E. J.: Total and ionic fluoride in milk, Caries Res., 15 ; 406-408, 1981.

8) Singer, L. and Ophaug, R.: Total fluoride intake of infants, Pediatrics, $63 ; 460-466$, 1979.

9) Taves, D. R.: Dietary intake of fluoride ashed (total fluoride) v. unashed (inorganic fluoride) analysis of individual foods, $\mathrm{Br}$. J. Nutr., 49 ; 295-301, 1983.

10) Dabeka, R. W. and Mckenzie, A. D.: Microdiffusion and fluoride-specific electrode determination of fluoride in infant foods-Collaborative study, J. Assoc. Off. Anal. Chem., 64 ; 1021-1026, 1981.

11) Beddows, C. G. and Kirk, D. : Determination of fluoride ion in bovine milk using a fluoride ion-selective electrode, Analyst, 106 ; 1341-1344, 1981.

12) Johnson, J. Jr. and Bawden, J. W.: The fluoride content of infant formulas available in 1985, Pediatr. Dent., 9 ; 33-37, 1987.

13) Latifah, R. and Duguid, R.: Measurements of ionic fluoride in milk, Annls Academy Med., 15 ; 299-304, 1986.

14) Spak, C. J., Hardell, L. I. and DeChateau, P.: Fluoride in human milk, Acta Pediatr. Scand., 72 ; 699-701, 1983.

15) McKnight-Hanes, M. C., Leverett, D. H., Adair, S. M. and Shields, C. P.: Fluoride content of infant formulas : soy-based formulas as a potential factor in dental fluorosis, Pediatr. Dent., 10 ; 189-194, 1988.

16) Latifah, R. and Razak, I. A.: Fluoride levels in infant formulas, J. Pedod., 13 ; 323327, 1989.

17) Chowdhury, N. G., Brown, R. H. and Shepherd, M. G.: Fluoride intake of infants in New Zealand, J. Dent. Res., 69 ; 18281833, 1990.

18) van Staden, J. F. and van Rensburg, S. D. J. : Improvement on the microdiffusion technique for the determination of ionic and ionizable fluoride in cows' milk, Analyst, $116 ; 807-810,1991$.

19) Rao, G. S.: Dietary intake and bioavailability of fluoride, Ann. Rev. Nutr., 4 ; 115-136, 1984.

20) Bessho, Y., Tomita, M. and Kaneko, Y.: Fluoride analysis of milk in Japan, Fluoride, $20 ; 30-35,1987$.

21) Tomita, M., Suzuki, S., Kuroiwa, S. and Kaneko, Y.: The application of a low temperature ashing system to pretreatment of biological materials for the determination of their fluorine contents, J. Dent. Health, 33 ; 183-196, 1983. (in Japanese)

22) Bessho, Y., Tomita, M. and Kaneko, Y.: Determination of total fluorine and ionizable 
fluorine levels in blood sera-A comparative study of various analytical methods, Tsunoda, H. and Yu, M.-H. (Editors), Fluoride Research 1985, Studies in environmental science, 27 ; Elsevier Science Publishers B. V., Amsterdam, 1986, pp. 73-80.

23) Tomita, M., Sugimura, T., Tadokoro, M. and Kaneko, Y.: Determination of tissue fluoride in rats following administration of an organic compound (Diflunisal), Fluoride, 22 ; 174-179, 1989.

24) Tomita, M., Tadokoro, M., Sugimura, T., Tada, S. and Kaneko, Y.: Determination of total fluorine in biological samples by pyrohydrolysis-gas chromatography, J. Dent. Health, 39 ; 767-776, 1989. (in Japanese)
25) Paez, D. M., de Bianchi, L. P., Gil, B. A., Dapas, O. and Coronato, R. G. : Biochemistry of fluorosis-Methods for evaluating fluoride in blood serum. A critical and comparative study, Fluoride, $13 ; 65-70,1980$.

26) Watanabe, T., Tsubakida, N., Miyagi, M. and Iwamoto, Y. : Fluorine in food I. Determination of total fluoride in powdered milk for babies, J. Dent. Health, 39 ; 387-392, 1989. (in Japanese)

27) Ekstrand, J.: Fluoride intake in early infancy, J. Nutr. 119 ; 1856-1860, 1989.

28) American Academy of Pediatrics, Committee on Nutrition: Fluoride supplementation, Pediatr. 77 ; 758-761, 1986. 